\title{
ANALISIS WACANA MATERI PEMERINTAHAN DARURAT REPUBLIK INDONESIA (PDRI) DALAM PEMBELAJARAN SEJARAH DI SMA
}

Oleh:

Tappil Rambe

Beni Hutajulu

\begin{abstract}
ABSTRAK
Penelitian ini bertujuan (1) untuk mengetahui karasteristik pembelajaran sejarah dalam komponen Kurikulum 2013 (2) untuk mengetahui materi pembelajaran tentang sejarah PDRI dalam Kurikulum 2013 dan (3) untuk mengetahui wacana materi pembelajaran PDRI dalam buku paket yang diterbitkan oleh penerbit swasta untuk kelas XII. Untuk memperoleh data yang diperlukan, maka peneliti menggunakan metode studi pustaka (library research). Tehnik untuk pengumpulan data dilakukan dengan cara menganalisis buku-buku yang berhubungan dengan pembelajaran sejarah dan juga buku paket sejarah kelas XII yang berkaitan dengan wacana sejarah PDRI. Dari penelitian yang dilakukan maka diperoleh hasil bahwa komponen pembelajaran sejarah untuk SMA dalam Kurikulum 2013 terdiri atas tujuan pembelajaran, struktur program dan muatan pembelajarn serta silabus dan juga Rencana Pelaksanaan Pembelajaran (RPP). Pembelajaran sejarah dalam tingkat SMA memiliki tujuan yang sangat penting dalam bidang kemampuan akademik, kesadaran sejarah dan juga rasa nasionalisme. Materi tentang PDRI dalam kurikulum 2013 terdapat dalam pelajaran kelas XII untuk semester I, dan materi PDRI dicantumkan dalam silabus, yaitu dengan kompetensi dasar 1.2 tentang " perkembangan ekonomi-keuangan dan politik pada masa awal kemerdekaan sampai tahun 1950. Wacana-wacana tentang materi pembelajaran tentang sejarah PDRI dalam buku paket memiliki karasteristik yang berbeda-beda, walaupun disusun berdasarkan kurikulum yang sama, yakni Kurikulum 2013. Wacana PDRI dalam buku paket tidak dituliskan sesuai dengan peristiwa sejarah PDRI. Selain itu, banyak fakta sejarah dari peristiwa PDRI tidak disebutkan dalam beberapa buku paket tersebut. Secara umum, bahwa wacana tentang PDRI dalam buku paket tersebut masih memiliki banyak kekurangan dari segi isi dan juga penyampaian materi PDRI tersebut.
\end{abstract}

Kata Kunci : Wacana PDRI, Pembelajaran Sejarah, Kurikulum 2013 


\section{PENDAHULUAN}

Pendidikan memiliki peran yang sangat strategis dalam mewujudkan sumber daya manusia yang kompeten dalam menghadapi perkembangan dan kemajuan teknologi serta modernisasi kehidupan. Pendidikan dimaksudkan untuk membentuk dan membina karakter dan kemampuan setiap peserta didik. Proses pembelajaran merupakan sebuah proses yang tidak dapat dipisahkan dan menjadi faktor pendukung dalam bidang pendidikan. Pembelajaran adalah perpaduan dari dua aktivitas, yaitu mengajar dan belajar. Aktivitas mengajar menyangkut peranan seorang guru dalam konteks mengupayakan terciptanya jalinan komunikasi harmonis antara pengajar itu sendiri dengan siswa. Tujuan pembelajaran adalah tercapainya perubahan perilaku atau kompetensi pada siswa setelah mengikuti kegiatan pembelajaran.

Salah satu media pendidikan yang diperlukan dalam melaksanakan proses pembelajaran di sekolah adalah buku cetak. Buku cetak sebagai salah satu media pendidikan yang menyediakan berbagai materi pembelajaran tertulis yang berkaitan dengan mata pelajaran tertentu. Dengan ketersediaan buku dapat mempermudah guru dalam menyampaikan materi pelajaran, dan bagi siswa dapat mempermudah dalam memahami materi pelajaran dan sekaligus dapat menambah ilmu pengetahuan yang dapat menunjang tercapainya tujuan pendidikan. Buku cetak sebagai salah satu bahan ajar jenis bahan cetak dengan substansinya adalah pengetahuan disusun berdasarkan analisis kurikulum, disusun untuk memudahkan guru dalam embelajaran dan siswa dalam belajar mencapai kompetensi yang ditetapkan kurikulum, dengan memperhatikan kebahasaan, kemenarikan, dan mencerminkan ide penulisnya. Buku yang memudahkan belajar siswa disebut buku siswa, dan buku yang memudahkan guru dalam melaksanakan pembelajaran disebut sebagai buku panduan guru/pendidik, masing-masing memiliki struktur dan komponen yang khas.

Salah satu hal yang perlu diperhatikan oleh seorang penulis dalam menyusun sebuah buku cetak yaitu dengan menganalisis kurikulum dan menyesuaikannya dengan materi- materi pelajaran yang akan di muat dalam buku cetak tersebut. Kurikulum 
berorientasi pada pengembangan intelektual siswa, dikembangkan oleh para ahli mata pelajaran sesuai dengan disiplin ilmu masing-masing. Menyusun materi pembelajaran yang harus dikuasai oleh siswa baik menyangkut data dan fakta konsep maupun teori.

Materi PDRI merupakan salah satu dari sebagian besar materi pelajaran yang tercantum dalam buku pelajaran sejarah khususnya untuk kelas XII dalam tingkat SMA. Materi tentang sejarah Pemerintahan Darurat Republik Indonesia (PDRI), merupakan sebuah materi pembelajaran yang membahas tentang pemerintahan darurat yang didirikan di bukittinggi pada tanggal 22 desember 1948. PDRI didirikan atas mandat dari Perdana Menteri Hatta kepada Syafruddin Prawiranegara yang waktu itu menjabat sebagai menteri kemakmuran. Berdirinya PDRI menjadi tonggak utama pemerintahan yang mempertahankan eksistensi kemerdekaan Indonesia dari pemberontakan Agresi Militer Belanda II. Dalam pemerintahan ini Syafruddin Prawiranegara menjabat sebagai ketua PDRI.

Sebagai sebuah materi dalam pembelajaran sejarah, materi PDRI menjadi bagian dari pembelajaran bagi siswa, Beragam jenis-jenis buku yang diterbitkan oleh para penulis dengan gaya penulisan yang berbeda-beda, akan memberikan penyampaian yang berbeda dalam menyajikan materi tentang PDRI dalam buku sejarah. Baik buku yang ditulis oleh sejarahwan, maupun penulis dalam buku paket. Sebagai sebuah bentuk perjuangan Indonesia dalam mempertahankan kemerdekaan, materi tentang PDRI ini sangat diperlukan dalam pembelajaran, sehingga dengan mempelajari peristiwa tentang PDRI tersebut dapat meningkatkan rasa nasionalisme peserta didik.

Penelitian ini dimaksudkan untuk menganalisis materi pelajaran tentang PDRI yang ada dalam kurikulum KTSP tahun 2006, seperti dalam silabus, Rencana Pelaksanaan Pembelajaran (RPP) dan juga buku paket yang berperan sebagai media pembelajaran yang paling dekat dengan siswa, yang secara umum memuat tentang wacana materi PDRI. 


\section{PEMBAHASAN}

\section{A. Karasteristik Pembelajaran Sejarah dalam Kurikulum 2013}

Kegiatan pembelajaran yang dibangun oleh guru dan siswa adalah kegiatan yang bertujuan. Sebagai kegiatan yang bertujuan, maka segala sesuatu yang dilakukan guru dan siswa hendaknya diarahkan untuk mencapai tujuan yang telah ditentukan. Dalam tingkatan tujuan pendidikan, diurutkan berdasarkan tujuan yang paling umum hingga tujuan yang paling khusus. Tujuan pendidikan nasional merupakan tujuan yang bersifat paling umum dan merupakan sasaran akhir yang harus dijadikan pedoman oleh setiap usaha pendidikan. Selanjutnya adalah tujuan Istitusional. Institusi dapat disebut juga sebagai lembaga. Sehingga tujuan institusional merupakan tujuan yang ingin dicapai oleh setiap sekolah atau setiap lembaga pendidikan. Tujuan institusional dapat didefenisikan sebagai kualifikasi yang harus dimiliki oleh setiap siswa setelah mereka menempuh atau dapat menyelesaikan program di suatu lembaga pendidikan tertentu.

Untuk tujuan yang lebih spesifik, tujuan pendidikan dikhususkan dalam tujuan Kurikuler. Tujuan kurikuler adalah tujuan yang ingin dicapai oleh setiap bidang studi. Tujuan kurikuler tersebut merupakan penjabaran dari tujuan institusional. Defenisi dari tujuan kurikuler sebagai kualifikasi yang harus dimiliki oleh anak didik setelah mereka mereka menyelesaikan suatu bidang studi tertentu dalam suatu lembaga pendidikan.

Dari tujuan tersebut bahwa peserta didik yang menempuh pendidikan di tingkat SMA harus mampu mengembangkan pemikiran yang luas terkait pembelajaran sejarah. Pembelajaran sejarah diharapkan mampu memberikan pemahaman yang luas terkait peristiwa sejarah yang terjadi di masa lampau dan pembelajaran sejarah mampu mengubah gaya berfikir peserta didik.

Selanjutnya untuk tujuan paling khusus, yaitu tujuan pembelajaran/tujuan instruksional. Dalam Rencana Pelaksanaan Pembelajaran, setiap materi tersebut memiliki tujuan yang telah dituliskan dalam RPP tersebut, sehingga setiap pertemuan ataupun setiap materi yang disampaikan memiliki tujuan nya masing-masing. Tujuan pembelajaran/instruksional merupakan bagian dari tujuan kurikuler, dapat 
didefenisikan sebagai kemampuan yang harus dimiliki oleh peserta didik setelah mereka mempelajari bahasan tertentu dalam bidang studi tertentu dalam satu kali pertemuan. Dari uraian tersebut, dapat dipahami bahwa tujuan Instruksional sebagai tujuan paling khusus dalam tujuan pendidikan yang umumnya terdapat dalam setiap Rencana Pelaksanaan Pembelajran (RPP). Tujuan pembelajaran umumnya dirumuskan oleh guru mata pelajaran dengan menyesuaikan silabus yang berlaku.

Sebagai sebuah ilmu pengetahuan, dalam struktur progam pembelajaran sejarah digolongkan kedalam kelompok pelajaran ilmu pengetahuan dan teknologi. Sebab, mata pelajaran sejarah adalah jenis mata pelajaran yang objeknya bersifat pengetahuan dan tergolong dalam ilmu pengetahuan sosial. Kelompok mata pelajaran tersebut dilaksanakan melalui muatan atau kegiatan pembelajaran sebagaimana diuraikan dalam peraturan pemerintah, yakni bahwa kelompok mata pelajaran ilmu pengetahuan dan teknologi pada SMA/MA/SMALB/Paket C, atau bentuk lain yang sederajat dilaksanakan melalui muatan dan/atau kegiatan bahasa, matematika, ilmu pengetahuan alam, ilmu pengetahuan sosial, keterampilan/kejuruan, teknologi informasi dan komunikasi, serta muatan lokal yang relevan.

Dalam kelompok mata pelajaran tersebut, dikelompokkan dalam beberapa mata pelajaran yang secara umum substansinya bersifat pengetahuan. Sebagai sebuah mata pelajaran yang bersifat sosial, maka pelajaran sejarah tergolong dalam kelompok mata pelajaran IPS. Muatan KTSP meliputi sejumlah mata pelajaran yang keluasan dan kedalamanya merupakan beban belajar bagi peserta didik pada satuan pendidikan. Sebagai sebuah mata pelajaran, sejarah memiliki posisinya masing-masing dalam tingkatan pembelajarannya. Dalam tingkat Sekolah Menengah Pertama ( SMP) sejarah digolongkan dalam kelompok mata pelajaran IPS terpadu. Sedangkan dalam tingkat SMA sendiri, mata pelajaran sejarah telah berdiri sendiri.

Struktur pembelajaran sejarah tersebut memiliki posisi masing-masing sesuai dengan lembaga pendidikannya. Menurut saya, bahwa muatan standar isi untuk mata pelajaran sejarah tersebut memberikan kontes pembelajaran dengan materi yang tersusun yang secara kronologis dan muatan isi tersebut dikembangkan dalam peristiwa 
sejarah dalam lintasan sejarah Indonesia, sedangkan untuk pengembangan yang selanjutnya bahwa muatan standar isi dalam pemebelajaran sejarah tersebut dikembangkan dalam perangkat pembelajaran, seperti silabus dan juga rencana pelaksanaan pembelajaran. Objek pembelajaran sejarah tersebut yang kemudian bahan pembelajaran sejarah bagi peserta didik dalam setiap tingkatan pendidikan.

Keseluruhan materi pelajaran sejarah yang telah diatur dalam Standar Isi dikembangkan dalam silabus dan perencanaan pembelajaran. Standar Kompetensi dan Kompetensi dasar dalam mata pelajaran sejarah lebih difokuskan pada pencapaian tujuan mata pelajaran sejarah dengan kemampuan akademik, yaitu melatih daya kritis peserta didik untuk memahami fakta sejarah secara benar dengan didasarkan pada pendekatan ilmiah dan metodologi keilmuan. Silabus berisi uraian program yang mencantumkan : 1) bidang studi yang diajarkan; 2) tingkat sekolah/madrasah, semester; 3) pengelompokan kompetensi dasar; 4) materi pokok; 5) indikator; 6) strategi pembelajaran; 7) alokasi waktu; dan 8) bahan/alat/media".

Setiap mata pelajaran yang diajarkan dalam lingkungan sekolah memiliki silabus masing-masing sesuai dengan tingkatan pembelajaran nya. Silabus yang berisikan materi-materi yang menjadi bahan pelajaran dalam proses belajar mengajar tersebut menjadi konsep utama yang membentuk materi pelajaran. Demikian dengan mata pelajaran sejarah, sebagai sebuah mata pelajaran yang diajarkan dalam lingkungan sekolah. Mata pelajaran sejarah memiliki silabus yang menjadi konsep pembelajarannya, dengan demikian seluruh materi sejarah yang diajarkan dalam pembelajaran terangkum dalam silabus.

\section{B. Materi pembelajaran tentang sejarah PDRI Dalam Kurikulum 2013}

Materi tentang sejarah PDRI merupakan salah satu materi pembelajaran yang dipilihkan sebagai materi pelajaran untuk kelas XII dalam tingkat SMA. Silabus dan Rencana Pelaksanaan Pembelajaran (RPP) merupakan perangkat yang paling dekat dengan pembelajaran, ketika berbica mengenai materi-materi pembelajaran dalam 
lingkungan pendidikan. Seluruh materi dalam pembelajaran dalam sebuah kurikulum dimuat dalam silabus dan selanjutnya dikembangkan dalam Rencana Pelaksanaan Pembelajaran (RPP).

\section{a. Silabus Sejarah Kelas XII Semester I}

Untuk materi tentang PDRI terdapat dalam kompetensi dasar 1.2. yakni : Menganalisis Perkembangan Ekonomi-Keuangan dan Politik pada Masa Awal Kemerdekaan sampai Tahun 1950". Kompetensi dasar tersebut dibentuk dan dikembangkan dari standar kompetensi yang telah ditetapkan sebelumnya. Untuk materi pembelajaran tentang PDRI terdapat dalam Kompetensi dasar 1.2. tentang Analisis perkembangan ekonomi-keuangan dan politik pada masa awal kemerdekaan sampai tahun 1950. Secara umum, PDRI termasuk dalam bagian perjuangan bangsa Indonesia dalam bidang militer dan politik, yang terjadi setelah kemerdekaan Indonesia yaitu pada saat Agresi Militer Belanda II, tepatnya pada tahun 1984-1949.

Untuk Kompetensi Dasar 1.2 tentang analisis perkembangan ekonomi-keuangan dan politik pada masa awal kemerdekaan samapai tahun 1950, terdiri dalam 5 bagian penjabaran materi pokok. Penjabaran Kompetensi Dasar tersebut mengembangkan materi pelajaran menjadi bagian yang lebih kecil. Materi pokok untuk standar kompetensi standar 1.2. yakni : (1) Kebijakan pemerintah Indonesia pada masa awal kemerdekaan (2) perkembangan situasi politik dan kenegaraan Indonesia di awal kemerdekaan (3) perjuangan Mempertahankan Kemerdekaan Indonesia Pada Tahun 1945-1949 (Konflik Indonesia-Belanda 1945-1949) (4) perbedaan strategi dan ideologi dalam menghadapi Belanda dan konflik antar kelompok politik di Indonesia (5) perjuangan diplomasi Indonesia dalam mempertahankan kemerdekaan.

Materi tentang PDRI terdapat dalam materi pokok tentang yang ketiga. yaitu, "Perjuangan memtertahankan kemerdekaan indonesia pada tahun 1945-1949 (konflik Indonesia dengan Belanda)". Dalam sejarah panjang perjuangan Indonesia, PDRI 
merupakan salah satu bagian dari perjuangan tersebut. PDRI muncul sebagai bentuk pemerintahan darurat yang bertujuan untuk mempertahankan keutuhan kemerdekaan Indonesia dari ancaman Agresi Militer Belanda pada tahun 1948. Secara umum sejarah PDRI termasuk dalam bagian perjuangan Indonesia dalam konflik Intern Indonesia dengan Belanda.

\section{b. Rencana Pelaksanaan Pembelajaran (RPP) Materi PDRI}

Dalam rencana pelaksanaan pembelajaran tersebut, merupakan rencana pembelajaran yang menyangkut tentang materi sejarah PDRI. Dalam kegiatan inti rencana pembelajaran, terdapat bahasan yang terkait dengan Agresi Militer Belanda II. Secara umum, materi tentang PDRI adalah bagian yang tidak terpisahkan dari Agresi Militer tersebut. Dalam penyusunan sebuah Rencana pelaksanaan Pembelajaran (RPP), memiliki karasteristik dan aturan penyusunan. Dalam RPP tersebut, merupakan rencana pembelajaran untuk SMA dengan program Ilmu Pengetahuan Sosial. Rencana pembelajaran tersebut merupakan perencanaan untuk jurusan sejarah dengan program IPS sesuai dengan bahasan peneliti. Untuk selanjutnya, terkait dengan kelas dan semester. Seperti yang telah disebutkan sebelumnya bahwa materi PDRI tersebut terdapat dalam kelas XII di Semester I.

Sebuah materi dalam rencana pembelajaran dikembangkan dari silabus yang digunakan. Jika disesuaikan dengan silabus untuk kelas XII semester I, maka dapat dilihat bahwa standar kompetensi dan kompetensi dasar sesuai dengan penjabaran dalam silabus. Dimana dalam Standar Kompetensi membahas tentang "Menganalisis Perjuangan Bangsa Indonesia sejak Proklamasi hingga Lahirnya Orde Baru”. Dalam Standar Kompetensi tersebut telah menjelaskan tentang perjuangan bangsa Indonesia, dalam hal ini materi tentang PDRI merupakan materi yang menceritakan tentang perjuangan bangsa Indonesia. 


\section{Wacana Materi Pembelajaran PDRI Dalam Buku Teks}

Sebagai sebuah materi pembelajaran sejarah di kelas XII, materi tentang PDRI ikut ambil bagian dalam penulisan buku paket sebagai media pembelajaran untuk kelas XII.

\section{Latar belakang PDRI}

Dalam analisis buku paket, wacana materi PDRI menjadi materi pelajaran dalam buku paket menuliskan latar belakang pembentukan PDRI tersebut dengan beberapa kajian dan penulisan yang berbeda. Secara umum, wacana tentang pembentukan PDRI dalam buku paket digambarkan dalam poin penting yang mengawali dan menjadi dasar pembentukan PDRI, yakni : (a) Pemberian kuasa penuh kepada Syafruddin Prawiranegara untuk membentuk Pemerintahan Darurat Republik Indonesia (PDRI). (b) Pemberian kuasa penuh kepada Maramis, L. N. Palar, dan Dr. Sudarsono yang sedang berada di India untuk membentuk pemerintahan RI di pengasingan. (c) Presiden dan Wakil Presiden RI memutuskan tidak mengungsi dan tetap tinggal di kota dengan kemungkinan berunding dengan Belanda dan KTN.

Wacana pembentukan PDRI dalam buku paket dapat disimpulkan dalam tiga poin penting tersebut yang menjadi awal pembentukan PDRI di Indonesia. Secara umum, dalam keseluruhan buku yang penulis analisis, menuliskan wacana tentang latar belakang pembentukan PDRI dengan gaya penulisan dan wacana yang berbeda, selain itu banyak fakta sejarah yang tidak dicantumkan ataupun dimunculkan dalam wacanawacana tersebut, seperti wacana terkait penandatanganan dan pegiriman radiogram hasil sidang tersebut terhadap Syafruddin, sedangkan wacana ini merupakan wacana penting dan merupakan fakta sejarah yang perlu diketahui oleh peserta didik, sehingga harus dimunculkan dalam buku bahan ajar sebagai latar belakang pembentukan PDRI, Akan tetapi dalam buku yang penulis analisis hanya beberapa buku yang menjelaskan peristiwa tersebut. 


\section{Pembentukan dan Susunan Kabinet PDRI}

Dalam wacana pembentukan PDRI penulis buku paket, memberikan gambaran yang berbeda tentang pembentukan dan susunan kabinet PDRI tersebut. Dalam wacana tulisan Herimanto, menuliskan bahwa pembentukan PDRI tersebut memerlukan waktu yang panjang sejak Belanda melakukan Agresinya di Yogjakarta dan Bukittinggi, dalam pembentukan PDRI tersebut.

Lain hal nya dengan buku yang dituliskan oleh Habib Mustopo, beliau tidak menjelaskan ataupun menuliskan materi tentang pembentukan maupun susunan kabinet PDRI dalam buku yang diterbitkan oleh penerbit Yudhistira tersebut. Sama hal nya dengan buku tulisan Magdalia, bahwa dalam buku nya juga, tidak menjelaskan tentang pembentukan PDRI tersebut, seakan PDRI tersebut telah dibentuk tanpa ada kendala. Selain itu, dalam buku tulisan Wayan Badrika juga tidak menuliskan susunan kabinet PDRI tersebut dalam buku nya, wcaan tentang penyusunan dan juga bentu kabinet PDRI tersebut, tidak dapat ditemukan dalam buku tersebut. Dalam buku-buku tersebut, hanya terlalu banyak berfokus pada Syafruddin saja, yang waktu itu sebagai perdana menteri PDRI.

Pentingnya sebuah wacana yang memunculkan fakta-fakta sejarah merupakan salah satu bukti dan kekuatan dalam pembelajaran sejarah tersebut, sebab dari fakta sejarah tersebut, pembaca akan percaya bahwa wacana sejarah tersebut benar adanya. Dengan adanya susunan kabinet tersebut seperti wacana yang dituliskan oleh Matroji dan juga Herimanto dalam bukunya, akan menunjukkan fakta bahwa PDRI tersebut benar adanya, dan terbukti dengan susunan kabinet yang dibentuk nya. Dengan adanya susunan kabinet tersebut maka eksistensi materi tentang PDRI dapat dipertahankan dalam sejarah nasional Indonesia. Dapat disimpulkan bahwa dari lima buku paket, hanya 2 yang menyinggung dan menuliskan wacana tentang pembentukan dan susunan kabinet PDRI. 


\section{Perjuangan PDRI}

Perjuangan PDRI sebagai sebuah Pemerintahan Darurat yang menjaga keutuhan dan mempertahankan kemerdekaan Indonesia merupakan kisah yang paling utama ketika berbicara tentang PDRI. Dalam buku paket, wacana perjuangan PDRi dituliskan masing masing penulis. Dalam wacananya, Herimanto memberikan gambaran bahwa PDRI berjuang dari satu hutan ke hutan lain secara bergantian, sehingga PDRI tersebut dikatakan sebagai pemerintahan mobilitas yang berpindah dari satu tempat ke tempat lain, wacana tersebut dapat ditemukan dan ditegaskan dari buku tulisan Mestika Zed ( 1997 : 4) yang menegaskan bahwa "PDRI menjalankan fungsi-fungsi administratifnya secara bergerilya dari hutan-hutan pedalaman Sumatera dan Jawa dan PDRI telah mengubah medan perjuangan dari kota ke pedesaan dan hutan-hutan di pedalaman, dan PDRI membuktikan bahwa dalil sejarah klasik kolonial tidak berlaku lagi lagi pada periode tersebut".

Sedangkan Magdalia menjelaskan perjuangan PDRI tersebut dengan menuliskan bahwa pada masa itu, PDRI dalam wilayah pertahanan nya dibagi menjadi dua bagian, yakni di Sumatera dan juga di Jawa. Di Sumatera di bentuk Markas Besar Komando Djawa yang dipimpin oleh Kolonel A.H. Nasution sedangkan di Sumatera dibentuk Markas Besar Komando Sumatera yang dipimpin oleh Kolonel Hidayat, dalam buku tersebut, beliau menuliskan bahwa perjuangan PDRI dilakukan dengan dua pertahanan tersebut, sehingga tidak mudah untuk ditaklukkan oleh belanda.

Jika Magdalia dan Herimanto menuliskan perjuangan PDRI tersebut secara luas dalam bukunya, lain hal nya dengan Habib Mustopo yang hanya menjelaskan eksistensi PDRI tersebut sebagai bentuk pertahanan Indonesia dengan membentuk Markas Besar di Jawa dan juga Sumatera, tanpa menjelaskan bentuk perjuangan PDRI tersebut yang bergerilya di hutan pedalaman sumatera dan jawa. Berbeda dengan perjuangan PDRI yang dituliskan oleh Wayan Badrika Secara luas, Wayan menjelaskan tentang perjuangan PDRI yang bergerak di Sumatera dan Jawa dalam mempertahankan eksistensi kemerdekaan Indonesia. Perjuangan PDRI dituliskan oleh 
Wayan dalam wacana nya yang menggambarkan keadaan pada masa tersebut, dimana PDRI bergerilya dan melakukan hubungan dengan dunia luar hanya dengan radio YBJ6. PDRI yang dibawah pimpinan Syafruddin Prawiranegara.

Sedangkan Matroji menuliskan perjuangan PDRI tersebut hanya sekilas yang berhubungan dengan tulisan Wayan Badrika yang mana PDRI berjuang dengan tetap melakukan komunikasi lewat radio terhadap wakil-wakil Indonesia di daerah daerah lain sehingga mengundang simpati masyarakat untuk ikut serta.

\section{Hubungan PDRI dengan Dunia Internasional dan Perundingan Roem-Royen}

Salah satu yang paling penting dalam peristiwa tentang PDRI adalah, perundingan Roem-Royen dan hubungan PDRI dengan dunia internasional yang memicu banyak nya dukungan Internasional terhadap Indonesia saat itu. Wayan Badrika menuliskan bahwa hubungan PDRI dengan dunia internasional dimulai dengan para diplomat Indonesia yang ada di luar negeri sehingga menarik perhatian para Negara-negara lain untuk ikut serta membantu Indonesia. Selanjutnya beliau menuliskan hubungan PDRI tersebut dengan dunia internasional sebagai sebuah kajian yang lebih luas dengan wacana yang lebih rangkum dan komplek. Wacana tentang hubungan ini dalam tulisan Wayan sangat terangkum dengan luas jika dibandingkan dengan wacana dalam buku Habib maupun Herimanto yang sama sekali tidak menyinggung tentang peristiwa ini, jika dilihat lebih jauh lagi. Bahwa peristiwa ini merupakan bagian dari perjuangan PDRI saat itu.

Dalam perundingan Roem Royen, keseluruhan buku yang penulis analisis menuliskan tentang perundingan tersebut dengan bagian yang berbeda beda. Perundingan Roem Royen pada masa itu menuai pro dan kontra dalam tubuh Indonesia sendiri. secara umum keseluruhan buku menuliskan tentang PDRI tersebut, akan tetapi hanya sebagian yang menuliskan tentang konflik internal tersebut.

Perjuangan PDRI dalam mempertahankan kemerdekaan Indonesia dari ancaman Agresi Militer Belanda bukan hanya dilakukan di Indonesia saja, dukungan dari dunia Internasional sangat besar sehingga melahirkan rasa simpatik dan dukungan dari 
berbagai Negara. Dalam buku paket, wacana tentang bentuk perjuangan internasional tersebut hanya terdapat dalam tulisan Wayan dan Matroji dan juga Magdalia walaupun dengan kajian yang singkat. Wacana tersebut menggambarkan bentuk hubungan yang dilakukan oleh PDRI dengan dunia internasional pada masa itu, sedangkan dalam buku tulisan Habib dan Herimanto tidak ditemukan wacana tentang hubungan tersebut.

\section{Akhir Perjuangan dan Pengembalian Mandat PDRI}

Bagian terakhir dalam wacana sejarah perjalanan panjang PDRI yang berlangsung selama 6 bulan bergerilya di hutan pedalaman adalah, pengembalian mandat. Sebagai sebuah Pemerintahan yang bersifat darurat ataupun sementara, maka pemerintahan PDRI harus dikembalikan kepada pemilik jabatan yang sebenarnya, yang waktu itu menjabat sebagai Perdana Menteri adalah Moh. Hatta.

Dalam wacananya, Wayan menjelaskan bahwa penyerahan mandat dilakukan setelah Yogjakarta kembali menjadi ibukota Negara. Dalam tulisan tersebut, Wayan menjelaskan adanya utusan Republik Indonesia untuk menemui para pemimpin PDRI dengan tujuan untuk membicarakan penyerahan mandat, hingga para pemimpin PDRI yang bergerilya selama 6 bulan kembali ke Yogjakarta dan dilakukan pengembalian mandat kepada Moh.Hatta dalam sidang istimewa yang dilakukan pada 13 juli 1949, sehingga pada saat itu pemerintahan kembali pada Kabinet Hatta. Dalam wacana tersebut, Wayan menjelaskan tentang pengembalian mandat hingga akhir dari PDRI tersebut, sama halnya dengan wacana Matroji. Walapun dengan kajian yang singkat, dalam wacananya Matroji menuliskan bahwa akhir dari PDRI tersebut adalah pengembalian mandat dari Syafruddin terhadap Moh. Hatta yang waktu itu secara sah menjabat sebagai Perdana Menteri.

Dua buku ini juga menyinggung tentang pengembalian mandat yang dilakukan pada tanggal 13 juli kepada Kabinet Hatta. Dengan adanya wacana tentang pengembalian mandat tersebut, maka akhir PDRI tersebut dapat digambarkan dengan jelas. Dalam buku yang peneliti analisis, hanya ada dua buku yang menggambarkan dan menuliskan tentang akhir PDRI dan pengembalian mandat sedangkan dalam buku 
Habib, Herimanto dan juga Magdalia tidak menyinggung tentang akhir PDRI tersebut maupun pengembalian mandat tersebut pada Moh. Hatta.

Beberapa wacana penulis lebih banyak bercerita dan menuliskan tentang latar belakang pembentukan PDRI tersebut, namun tidak menuliskan tentang perjuangan maupun akhir dari PDRI itu sendiri. Dengan demikian, ketika wacana tersebut berada di tangan peserta didik, maka mereka akan memahami latar belakang pembentukan PDRI namun tidak paham akhir dan nasib dari PDRI itu sendiri.

\section{III.PENUTUP}

Dalam komponen Kurikulum 2013, karasteristik pelajaran sejarah terdiri atas, tujuan pembelajaran, struktur program dan muatan pembelajaran serta silabus dan rencana pelaksanaan pembelajaran sejarah. Pembelajaran sejarah memiliki tujuan yang sangat penting dalam membentuk dan juga mengembangkan kecakapan peserta didik dalam bidang kemampuan akademik, kesadaran sejarah, dan juga rasa nasionalisme. Sedangkan dalam susunan program dan muatan kurikulum 2013, pelajaran sejarah tergolong dalam kelompok mata pelajaran ilmu pengetahuan dan teknologi, yakni Ilmu Pengetahuan Sosial (IPS) yang kemudian dikembangkan secara khusus menjadi pelajaran sejarah yang berdiri sendiri.

Dalam K13, Materi sejarah tentang PDRI terdapat dalam pembelajarn sejarah untuk kelas XII dalam semester I, yakni dalam Kompetensi Dasar 1.2 tentang perkembangan ekonomi-keuangan dan politik pada masa awal kemerdekaan sampai tahun 1950. Sedangkan dalam materi pokok, materi sejarah PDRI terdapat dalam materi pokok yang ketiga dalam silabus, yaitu tentang konflik Indonesia- Belanda tahun 1945-1949. Sesusai dengan silabus tersebut, maka sebagai materi pembelajaran, sejarah tentang PDRI tersebut dikembangkan kedalam rencana Pelaksanaan Pembelajaran ( RPP )

Wacana materi pembelajaran tentang sejarah PDRI dalm buku paket memiliki banyak perbedaan. Beberapa penulis menuliskan peristiwa latar belakang PDRI tersebut secara lengkap, namun tidak menjelaskan perjuangan maupun susunan kabinet 
PDRI tersebut, selain itu dalam beberapa buku juga menggambarkan tentang perjuangan dan latar belakang PDRI namun menghilangkan susunan kabinet dan juga akhir dari PDRI tersebut. Secara umum dalam buku yang penulis analisis banyak yang tidak menunjukkan fakta-fakta yang akurat dalam menuliskan tentang sejarah PDRI tersebut sebagai dalam buku paket.

\section{REFERENSI}

Aman. (2011). Model Evaluasi Pembelajaran Sejarah. Yogjakarta : Ombak Djoned, Marwati. (1993). Sejarah Nasional Indonesia VI. Jakarta : Balai Pustaka Eriyanto. (2001). Analisis Wacana: Pengantar Analisis Teks Media. Yogyakarta: LKIS Hasan, Hamid. (2009). Evaluasi Kurikulum. Bandung : Remaja Rosda Karya. . (2012). Pendidikan Sejarah Indonesia. Bandung : Rizqi Press

Ibrahim \& Nana. (2010). Perencanaan Pengajaran. Jakarta : Rineka Cipta. I Gde Widja. (1989). Pengantar Ilmu Sejarah : Sejarah dalam Perspektif Pendidikan. Semarang : Angkasa

Isjoni. (2007). Pembelajaran Sejarah Pada Satuan Pendidikan. Bandung. Alfabeta Majid, Abdul. (2008). Perencanaan Pembelajaran. Bandung : Remaja Rosda Karya. Mulyasa. (2008). Kurikulum Tingkat Satuan Pendidikan (KTSP). Bandung : Rosadakarya.

Rasjid, Mohammad. (1982). Di Sekitar PDRI (Pemerintah Darurat Republik Indonesia). Jakarta : Bulan Bintang.

Sanjaya, Wina. (2011). Kurikulum dan Pembelajaran. Jakarta : Kencana. (2011). Strategi Pembelajaran. Jakarta : Kencana

Salim, Islam. (1995). Terobosan PDRI dan Peranan TNI. Jakarta : Penebar Swadaya. Sagala, Syaiful. (2010). Konsep dan Makna Pembelajaran. Bandung: Alfabeta Sjamsuddin, Helius. (2007). Metodologi Sejarah. Yogyakarta: Ombak. Yoce Aliah. (2009). Analisis Wacana Kritis. Bandung: Yrama Zed, Mestika. (1997). Pemerintah Darurat Republik Indonesia. Jakarta : Pustaka Utama Grafiti 